Original Article

\title{
PHARMACOGNOSTIC STUDIES OF DALBERGIA SISSO ROXB.
}

\author{
IJAZ ALI ${ }^{1}$, GHAZALA H. RIZWANI ${ }^{1,2}$, HUMA SHAREEF ${ }^{*}$, SOHAIL KHAN ${ }^{1}$
}

1Department of Pharmacognosy, Faculty of Pharmacy, University of Karachi, ${ }^{2}$ Faculty of Pharmacy, Hamdard University, Karachi, ${ }^{3}$ Institute of Pharmaceutical Sciences, Jinnah Sind Medical University Karachi

Email:phr_huma@hotmail.com

Received: 03 May 2016 Revised and Accepted: 05 0ct 2016

\section{ABSTRACT}

Objective: Present study was aimed to standardize the leaves, pods, and bark of Dalbergia sisso Roxb (Fabaceae) plant which is one of the most important species of Pakistan and used in different ailments.

Methods: Powders of dried parts of this plant were used for macroscopic and microscopic, histological, fluorescence, micro chemical, proximate, infra-red spectroscopic examinations and extract were used for preliminary phytochemical examination. These entire tests were performed as per World Health Organization (WHO) standards.

Results: In preliminary phytochemical analysis D. sisso carbohydrates, alkaloids, and tannins were detected in the pod while leaves contain carbohydrates alkaloids and flavonoids. The different cellular structure provides the basis of different parts identifications like stomata in leave (A), schlerides in pods (B) and tissues in bark (C) parts of the powdered plant. Proximate analysis showed the high level of moisture content and ash values of A, B and C samples. The fluorescence behavior of powdered material of A, B and C revealed the coloration of these samples under different wavelength. Fourier transform infrared spectroscopy (FTIR) established the spectrum include aromatic and aldehyde based functional groups for the all three powdered samples of $D$. sisso Roxb.

Conclusion: This research work was performed for the standardization of the plant $D$. sisso Roxb. as per WHO recommendations and we established the proper identification profile of the plant and its parts.

Keywords: Powder microscopy, Dalbergia sisso Roxb, Phytochemical analysis, Fabaceae, Histology

(C) 2016 The Authors. Published by Innovare Academic Sciences Pvt Ltd. This is an open access article under the CC BY license (http://creativecommons.org/licenses/by/4. 0/) DOI: http://dx.doi.org/10.22159/ijpps.2016v8i12.12559

\section{INTRODUCTION}

Large genus Dalbergia is widely distributed in the tropical region of the world including central and South America, Africa Madagascar, and Southern Asia having approximately 300 species and belongs to the pea family Fabaceae formerly named as Pappilionacea [1]. The most important species Dalbergia sisso Roxb is native to foothills of Himalayas India, Pakistan and Nepal. Basically, it is cultivated in forest plantations but also growing along the river bank, roadsides, railway lines, water channels and Borders of the agricultural fields [2]. In Pakistan, it is widely distributed in the mega cities of Punjab and Sindh province and plays its role in reducing the pollution.

The various chemical constituents have been isolated from the different parts of this plant. Leaves contain Isoflavone-0-glycoside, flowers have Biochanin A, tectorigenin, 7, 4 dimethyl tectorigenin and 7-0-methyle tectorigenin. Immature and mature pods are full of Mesoinisitol, 7-0-methyle tectorigenin and 4'-rhamnoglucoside, Isocaviumin, tectorigenin, Dahlberg in, caviunin and tannins type compounds. Dalberginone, dalbergin, methyl dalbergin and dalbergichromene were isolated from its stem bark whereas, Dalbergin, nordalberginones, dalbergichromene, fixid oil and essential oils from heartwood. Wood of this plant is used for fuel and furniture making purpose. The plant has been cultivated as a venue tree and also has a great medicinal value.

Ethanolic leave extract show osteogenic activity in calvarial osteoblast cultures and also proved efficacious in isoproterenolinduced myocardial injury in rats [3, 4]. Aqueous and methanolic extracts of stem bark of this plant have shown antioxidant and Antidiabetic activity $[5,6]$. It is used as folk remedy for excoriation, gonorrhea and skin ailments [7]. Ayurveda prescribed the leaf juice for eye ailments, considering whereas the wood and bark are used as an abortifacient, anthelmintic, antipyretic, aphrodisiac, expectorant and refrigerant. Wood has also used in Unani medicine for blood disorders, burning sensations, eye and nose diseases scabies, scalding urine stomach problems and syphilis.
The aim of this study is to provide such information that can proceed as reference information for correct identification of exacting plant and also will be valuable in making a monograph of the Dibergia sisso plant. Moreover, it will operate the sample as a tool to perceive adulterants and substituent. The detailed authentic sample identification as per WHO requirement for the standardization of different parts of Dibergia sisso not reported therefore it will provide the basis for safe, effective equality products to the market by the utilization of standard herbal drug as raw material or as an active herbal drug.

\section{MATERIALS AND METHODS}

\section{Collection and Identification of plant materials}

The leaves (A) pods (B) and bark (C) of Dalbergia sisso Roxb. were collected in the month of December 2014 from the premises of University of Karachi. The plant was identified by Prof. Dr. Ghazala. H. Rizwani, Department of Pharmacognosy, University of Karachi. The voucher specimens with numbered $104 \mathrm{~A}, 104 \mathrm{~B}$ and $104 \mathrm{C}$ respectively were deposited in the herbal museum of Department of Pharmacognosy, Faculty of the Pharmacy University of Karachi.

\section{Chemicals and reagents}

All chemicals were used of analytical grade and reagents were prepared in the distilled water. methanol, ethanol, n-butanol, ethyl acetate, chloroform, sulphuric acid, acetic acid, hydrochloric acid, nitric acid, water, vanillin, iodine, chloral hydrate, glycerin, ferric chloride, Canada balsam,saffranine, malachite green, clove oil, nitrocellulose, amylacetae, sodium hydroxide, ammonium ceric sulphate, Molisch's reagent, Salwaski's reagent, Dragndroff's reagent, and Liebermann Burchard's reagent were used.

\section{Extraction}

Sample A, B and C of Dalbergia sisso Roxb. were separated, cleaned and weighed (10Kg each) properly,chopped into small pieces. Then these parts were percolated separately in absolute methanol (Merck, 
Germany) at room temperature for fifteen days and evaporated under reduced pressure and controlled temperature on the rotary evaporator (Eyela, Japan). After obtaining the extracts, the materials were again percolated in the same way. This procedure was repeated thrice. The 55g (A) 46g (B) and 50g (C) residues were obtained.

\section{Preliminary phytochemical examination}

The portion of all methanolic extracts was utilized for the detection of various primary and secondary compounds in A, B and C parts of the plant. Preliminary phytochemical analysis including carbohydrate (Molisch's Reagent), terpenoids (Salwaski's reagent), alkaloids (Dragndroff's reagent) steroids (Liebermann Burchard's reagent) tannins and flavonoids were performed on each methanolic extract, according to standard procedures [8].

\section{Proximate examination}

Proximate parameters including loss on drying, moisture content, and dry matter weight were determined in drying oven (DHG9053A). Percentage of total ash was also determined at $800^{\circ} \mathrm{C}$ by using Muffle Furnace (A product of PCSIR, MF-102) [9].

\section{Pharmacognostic examination}

The macroscopic and microscopic evaluations of sample A, B and C were carried out according to WHO recommendations.

\section{Macroscopy}

Macroscopic or organoleptic study of sample A,B and C were evaluated after washing of plant with distilled water, dried it in hot air oven at 35 ${ }^{\circ} \mathrm{C}$ and grinded with the help of electric grinder. Color, odor, and taste of powdered drug were performed by sensory organ. [10]

\section{Microscopy}

Microscopic examination of powdered sample A, B and C were performed by using a microscope (Nikon Co. Ltd., Japan). A small amount of fine powdered of A, B, and C were placed on a microscopic slide, mixed with $10 \% \mathrm{w} / \mathrm{v}$ aqueous chloral hydrate solution and covered with a coverslip then was placed microscope and observed carefully for identification of different cellular diagnostic features. Then same procedure was repeated by using $5 \% \mathrm{w} / \mathrm{v}$ aqueous solution of iodine and $50 \% \mathrm{w} / \mathrm{v}$ aqueous solution of glycerin $[11,12]$.

\section{Histological examinations}

The histological examination of sample A, B, C was carried out by cutting the transverse sections of each part and examined one by one under a microscope. [13]

\section{Fluorescence examination}

Fluorescence analysis was performed with a powdered form of the plant. In this analysis, organic compounds absorb radiations of a specific wavelength and many of them also re-emit some radiations. The characters of powdered parts of the plant were studied by using UV radiations at two different wavelengths i. e $254 \mathrm{~nm}$ and $336 \mathrm{~nm}$ [14].

\section{Microchemical examinations}

The color examination was performed for powdered parts of the plant $(A, B, C)$. Behaviors of the powders were examined by treating them with chemical reagents such as water $5 \%$ Ferric chloride, $10 \%$ Sulphuric acid, 4\% Sodium hydro oxide and Chloroform [11].

\section{FT-IR fingerprinting}

The fine powder of plant parts A, B and C was analyzed on FT-IR Spectrophotometer (Thermo Spectronic Model, Helios Alpha No UVA 090714, England) and the spectrum was recorded.

\section{RESULTS}

\section{Preliminary phytochemical examination}

The preliminary phytochemical examination of plants parts A, B and $\mathrm{C}$ was showed in table 1 . It is revealed that carbohydrates, alkaloids gives positive in all parts of plant whereas steroids and terpenoids were absent in all these three parts.

\section{Proximate examination}

The percentages of moisture content, ash value of the samples A, B and $\mathrm{C}$ were present in a fig. 1 .

\section{Pharmacognostic examination}

The color, odor and taste of sample A, B and C are presented in table 2 and their diagnostic features were enlisted in table 3 . Whereas, the diagrammatic presentations are shown in fig. 2 and 3.

Table 1: Preliminary phytochemical examination of different parts of $D$. Sisso Roxb

\begin{tabular}{llll}
\hline S. No. & Test & A & B \\
\hline 1. & Carbohydrate & Positive & Positive \\
2. & Alkaloids & Positive & Positive \\
3. & Steroids & Negative & Negative \\
4. & Tannins & Negative & Positive \\
5. & Terpenoids & Negative & Negative \\
6. & Flavonoids & Positive & Positive \\
\hline
\end{tabular}

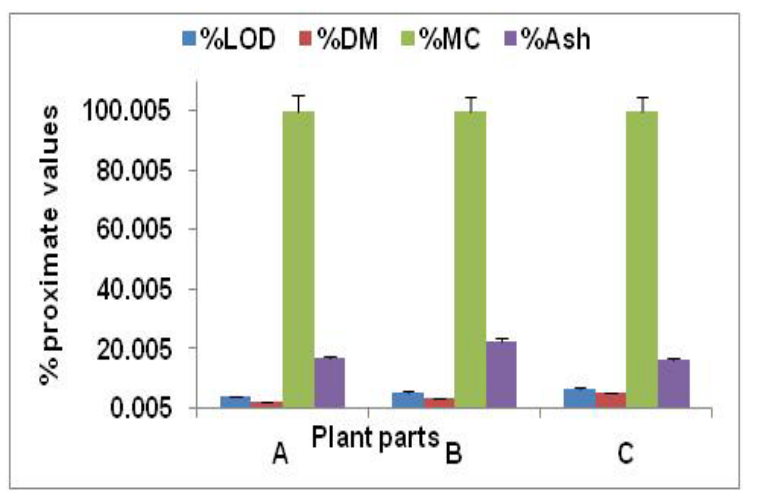

Fig. 1: Proximate Examination of different parts of $D$. Sisso Roxb, Data are expressed as means \pm standard deviation where $\mathbf{n}=3$

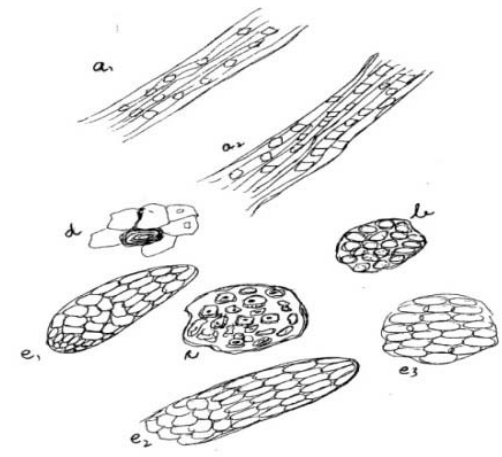

Fig. 2: Powder microscopy of parts B of Dalbergia sisso Roxb, (a) Fibers (b) Cells containing starch grains (c) Calcium oxalate prismlike cells (d) Ground tissues (e) Different types of Schlerides 
Table 2: Macroscopic features of A, B and C parts of D. sisso Roxb

\begin{tabular}{|c|c|c|c|}
\hline Properties & $\mathbf{A}$ & B & $\mathbf{C}$ \\
\hline Color & Lush green & Yellowish Brown & Light Brown to Dark grey \\
\hline Odor & Slightly waxy & No Characteristics & Dusty Pungent \\
\hline Fracture & Leathery/Shiny & Complete & Tough and Rough \\
\hline External Making & Apiculate apex & $\begin{array}{l}\text { Shiny, wrinkled, sharp lateral edges, with pointed at one end and slightly blunt } \\
\text { at another end. Ventral and dorsal sides having prominent, } 3 \text { marks which } \\
\text { shows seeds embracing cavities at everything distance with dark brown mark. }\end{array}$ & $\begin{array}{l}\text { Ridges, Shed in narrow } \\
\text { strips }\end{array}$ \\
\hline Internal Making & Polished surface. & 2-4 cavities are present and a seed is present in each cavity. & Slightly Smooth \\
\hline Size & $15 \mathrm{~cm}$ long. & $4-8 \mathrm{~cm}$ long and $1 \mathrm{~cm}$ wide & $2.5 \mathrm{~cm}$ Long \\
\hline Shape & Suborbicular & Lanceolate & Rectangular \\
\hline Taste & $\begin{array}{l}\text { Slightly sweet } \\
\text { and slimy }\end{array}$ & Insipid & Slimy \\
\hline
\end{tabular}

Table 3: Diagnostic features of the powdered parts of $D$. Sisso Roxb

\begin{tabular}{|c|c|c|c|c|c|c|}
\hline S. No. & $\mathbf{A}$ & & B & & $\mathrm{C}$ & \\
\hline 1 & Lamina & $\begin{array}{l}\text { The isobilateral shape of diacytic } \\
\text { stomata's are present. }\end{array}$ & $\begin{array}{l}\text { Calcium } \\
\text { oxalate }\end{array}$ & $\begin{array}{l}\text { Rare Calcium oxalate crystals } \\
\text { are seen in powders of pods }\end{array}$ & $\begin{array}{l}\text { Starch } \\
\text { Grains }\end{array}$ & $\begin{array}{l}\text { Free starch grains } \\
\text { are present }\end{array}$ \\
\hline 2 & Epidermis & $\begin{array}{l}\text { Upper and lower epidermis with } \\
\text { rectangular thin epidermal cells, } \\
\text { lower epidermis, contain oil contents } \\
\text { vigorously }\end{array}$ & Schlerides & $\begin{array}{l}\text { Schlerides found to contain } \\
\text { high deposition of lignin } \\
\text { along with tannin }\end{array}$ & $\begin{array}{l}\text { Ground } \\
\text { Tissues }\end{array}$ & $\begin{array}{l}\text { Some Ground } \\
\text { tissues are seen }\end{array}$ \\
\hline 3 & $\begin{array}{l}\text { Calcium } \\
\text { Oxalate }\end{array}$ & $\begin{array}{l}\text { Crystals or prism-like cells are } \\
\text { present more abundantly in the drug. }\end{array}$ & Fibers & $\begin{array}{l}\text { Elongated lignified and no } \\
\text { lignified fibers are present in } \\
\text { the powders of the pods }\end{array}$ & Fibers & $\begin{array}{l}\text { Compacted fibers } \\
\text { are present }\end{array}$ \\
\hline 4 & Fibers & $\begin{array}{l}\text { Groups of fibers contain some lignin } \\
\text { content are present some of the fibers } \\
\text { contain calcium oxalate crystals. }\end{array}$ & $\begin{array}{l}\text { Starch } \\
\text { Grains }\end{array}$ & $\begin{array}{l}\text { Free starch grains and } \\
\text { compacted grains containing } \\
\text { cells are also seen }\end{array}$ & $\begin{array}{l}\text { Hexagonal } \\
\text { Cells }\end{array}$ & $\begin{array}{l}\text { Hexagonal } \\
\text { epidermal cells }\end{array}$ \\
\hline 5 & $\begin{array}{l}\text { Lignified } \\
\text { Cells }\end{array}$ & $\begin{array}{l}\text { Elongated thickly lignified fragment } \\
\text { are found abundantly }\end{array}$ & $\begin{array}{l}\text { Ground } \\
\text { tissue }\end{array}$ & $\begin{array}{l}\text { Rounded ground tissue are } \\
\text { occasionally found. }\end{array}$ & $\begin{array}{l}\text { Rectangular } \\
\text { Cells }\end{array}$ & $\begin{array}{l}\text { Some rectangular } \\
\text { cells seen }\end{array}$ \\
\hline
\end{tabular}

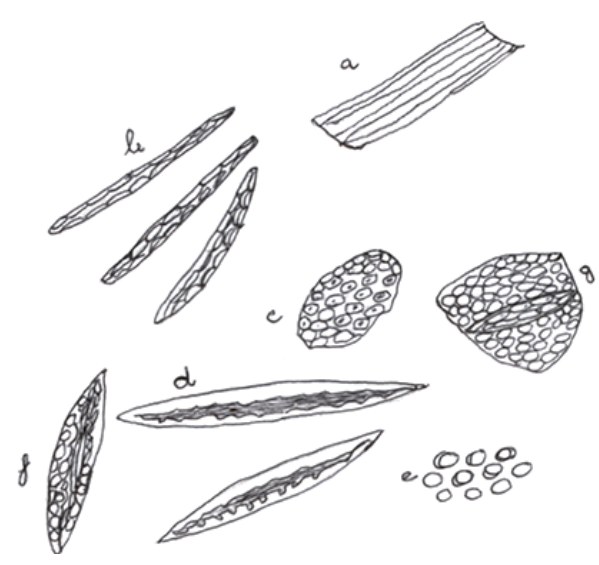

Fig. 3: Powder microscopy of A of D. sisso Roxb, (a) Group of fibers (b) Epidermis (c) Calcium oxalate (d) Fibers (e) Lignified cells (f) Starch grains

\section{Histological examination}

The plant histology showed different types of cellular structures which are enlisted in table 4 and their cellular shapes can be identified in the fig. 4 and 5.

\section{Florescence examination}

The fluorescence behavior of powdered material of A, B and C was established under a day, with UV minimum and maximum wavelengths of lights and the color of powdered drugs are revealed green to brown as indicated in table 5 .

\section{Micro Chemical Examination}

Different chemical reagents give particular behavior with a powdered sample of A, B, and C and only $5 \%$ Ferric chloride gives no color with all three samples table 6 .

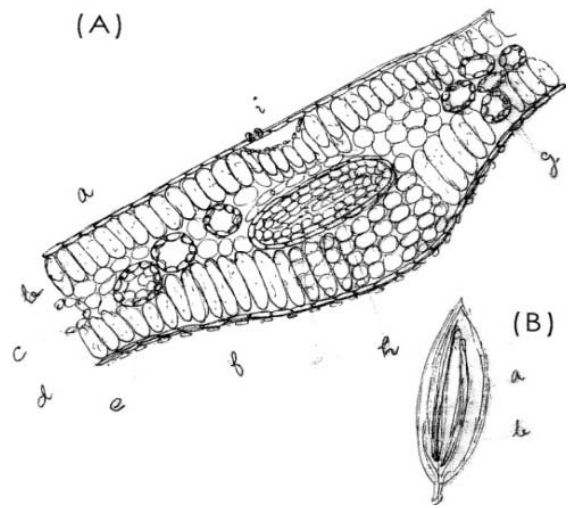

Fig. 4: Transverse section of A and B of D. Sisso Roxb, A. (a) Epidermal layer (b) Palisade Parenchyma (c) Collenchyma (d) Palisade (e)Pericycle fiber (f) Oil contents (g)Fibrovascular bundle (h)Pith (i)Stomata, B. (a)Embryo (b) Endospermic cell

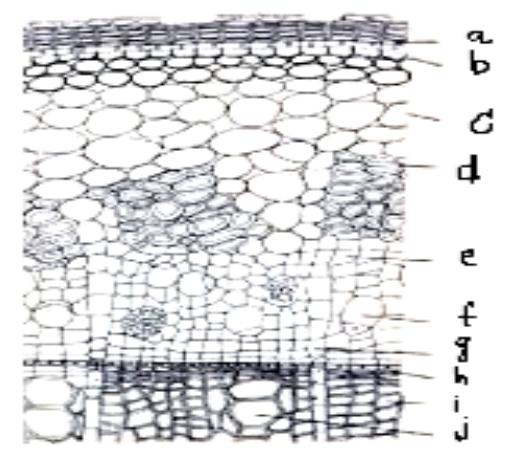

Fig. 5: Transverse section of part C of D. Sisso Roxb, (a) Cork (b) Cork cambium (c) Schaleren chyma (d)Parenchyma (e) Sieve tube (f) Ray (g) Vascular Cambium (h) Xylem fibers (i) Vessels 
Table 4: Transverse section of A, B and C of D. Sisso Roxb

\begin{tabular}{|c|c|c|}
\hline A & B & C \\
\hline Epidermal Layer & Embryo & Cork \\
\hline Upper and lower & $\begin{array}{l}\text { A thread like linear Embryo is present more } \\
\text { prominently. }\end{array}$ & $\begin{array}{l}\text { Outermost layer of rectangular } \\
\text { cells }\end{array}$ \\
\hline Stomata Diacytic & Endospermic cells & Cork cambium \\
\hline $\begin{array}{l}\text { Stomata seen in the wide stomatal chamber } \\
\text { composed of small thin cells. }\end{array}$ & $\begin{array}{l}\text { Epidermal cells containing oil globules and portentous } \\
\text { matter along with rich lignified fibers present. }\end{array}$ & $\begin{array}{l}\text { Underlying the cork cells Cork } \\
\text { cambium is present }\end{array}$ \\
\hline Palisade Parenchyma & & Schaleren chyma \\
\hline $\begin{array}{l}\text { Underlying the epidermis elongated parenchyma } \\
\text { columnar cells with elongated chloroplasts. }\end{array}$ & . & $\begin{array}{l}\text { Bundles of Phloem fibers are } \\
\text { seen. }\end{array}$ \\
\hline Collenchyma & & Collenchyma \\
\hline $\begin{array}{l}\text { Central region of midrib composed of moderate size } \\
\text { spherical collenchyma cells }\end{array}$ & 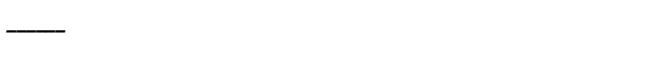 & $\begin{array}{l}\text { Consisting of phloem cells and } \\
\text { sieve-tube. }\end{array}$ \\
\hline Fibers Vascular Bundles & & Ray \\
\hline $\begin{array}{l}\text { Rounded Fibro-vascular bundles on the both sides } \\
\text { towards laminal region are present }\end{array}$ & 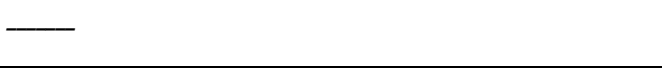 & $\begin{array}{l}\text { It consists of a layer of square } \\
\text { shaped cells. }\end{array}$ \\
\hline
\end{tabular}

Table 5: Florescence analysis of A, B and C parts of D. Sisso Roxb

\begin{tabular}{|c|c|c|c|c|c|c|c|c|c|}
\hline \multirow[t]{3}{*}{ Treatment with reagent } & \multicolumn{9}{|l|}{ Observations } \\
\hline & \multicolumn{3}{|l|}{$\mathbf{A}$} & \multicolumn{3}{|l|}{ B } & \multicolumn{3}{|l|}{$\mathbf{C}$} \\
\hline & $\begin{array}{l}\text { At ordinary } \\
\text { light }\end{array}$ & $\begin{array}{l}\text { At } 254 \\
\text { nm }\end{array}$ & $\begin{array}{l}\text { At } 336 \\
\text { nm }\end{array}$ & $\begin{array}{l}\text { At ordinary } \\
\text { light }\end{array}$ & $\begin{array}{l}\text { At } 254 \\
\text { nm }\end{array}$ & $\begin{array}{l}\text { At } 336 \\
\text { nm }\end{array}$ & $\begin{array}{l}\text { At ordinary } \\
\text { light }\end{array}$ & $\begin{array}{l}\text { At } 254 \\
\text { nm }\end{array}$ & $\begin{array}{l}\text { At } 336 \\
\text { nm }\end{array}$ \\
\hline Powder as such & Green & $\begin{array}{l}\text { Dull } \\
\text { Green }\end{array}$ & $\begin{array}{l}\text { Dark } \\
\text { Green }\end{array}$ & Brown & $\begin{array}{l}\text { Light } \\
\text { Brown }\end{array}$ & $\begin{array}{l}\text { Dark } \\
\text { brown }\end{array}$ & Brown & $\begin{array}{l}\text { Light } \\
\text { Brown }\end{array}$ & $\begin{array}{l}\text { Dark } \\
\text { brown }\end{array}$ \\
\hline $\begin{array}{l}\text { Powder treated with } 1 \mathrm{~N} \\
\mathrm{NaOH} \text { in } \mathrm{MeOH}\end{array}$ & Green & $\begin{array}{l}\text { Dull } \\
\text { Green }\end{array}$ & $\begin{array}{l}\text { Dull } \\
\text { green }\end{array}$ & Light Brown & $\begin{array}{l}\text { Off } \\
\text { white }\end{array}$ & $\begin{array}{l}\text { Dark } \\
\text { brown }\end{array}$ & Light Brown & $\begin{array}{l}\text { Off } \\
\text { white }\end{array}$ & $\begin{array}{l}\text { Dark } \\
\text { brown }\end{array}$ \\
\hline $\begin{array}{l}\text { Powder treated with } 1 \mathrm{~N} \\
\mathrm{HCl}\end{array}$ & Bright Green & Green & $\begin{array}{l}\text { Light } \\
\text { Green }\end{array}$ & Brown & $\begin{array}{l}\text { Light } \\
\text { Brown }\end{array}$ & Brown & Brown & $\begin{array}{l}\text { Light } \\
\text { Brown }\end{array}$ & Brown \\
\hline $\begin{array}{l}\text { Powder treated with } 50 \% \\
\mathrm{H}_{2} \mathrm{SO}_{4}\end{array}$ & Dark Green & $\begin{array}{l}\text { Dark } \\
\text { Green }\end{array}$ & Blue & Slight turbid & $\begin{array}{l}\text { Dull } \\
\text { Brown }\end{array}$ & $\begin{array}{l}\text { Dark } \\
\text { Brown }\end{array}$ & Slight turbid & $\begin{array}{l}\text { Dull } \\
\text { Brown }\end{array}$ & $\begin{array}{l}\text { Dark } \\
\text { Brown }\end{array}$ \\
\hline $\begin{array}{l}\text { Powder treated } \\
\text { with } 50 \% \mathrm{HNO}_{3}\end{array}$ & Light Green & $\begin{array}{l}\text { Dark } \\
\text { Green }\end{array}$ & $\begin{array}{l}\text { Dark } \\
\text { Green }\end{array}$ & Light Brown & $\begin{array}{l}\text { Light } \\
\text { Red }\end{array}$ & Red & Light Brown & $\begin{array}{l}\text { Light } \\
\text { Red }\end{array}$ & Red \\
\hline $\begin{array}{l}\text { Powder mounted in } \\
\text { nitrocellulose in amyl } \\
\text { acetate }\end{array}$ & Green & $\begin{array}{l}\text { Dark } \\
\text { Green }\end{array}$ & $\begin{array}{l}\text { Dull } \\
\text { Green }\end{array}$ & Dull Brown & Brown & $\begin{array}{l}\text { Dark } \\
\text { Brown }\end{array}$ & Dull Brown & Brown & $\begin{array}{l}\text { Dark } \\
\text { Brown }\end{array}$ \\
\hline
\end{tabular}

Table 6: Microchemical analysis of A, B and C parts of D. Sisso Roxb

\begin{tabular}{|c|c|c|c|}
\hline \multirow[t]{2}{*}{ Reagents } & \multicolumn{3}{|l|}{ Color observations } \\
\hline & A & B & C \\
\hline Absolute alcohol & Light green & No color change was seen & No color change was seen \\
\hline Ferric Chloride 5\% & No color change & No color change was seen & No color change was seen \\
\hline Sulphuric acid $10 \%$ & Turbidity seen & No color change was seen & Turbidity seen \\
\hline Sodium Hydroxide $4 \%$ & Light green color seen & Light brown color seen & Light brown color seen \\
\hline Chloroform & Light green color & No color change was seen & No color change was seen \\
\hline
\end{tabular}

\section{FT-IR spectrum}

The IR spectroscopy was developed for the identification of different functional groups present in the samples A, B and C.

Spectra are shown in fig. 6 (A, B and C) and their spectral behavior is illustrated in table 7 .

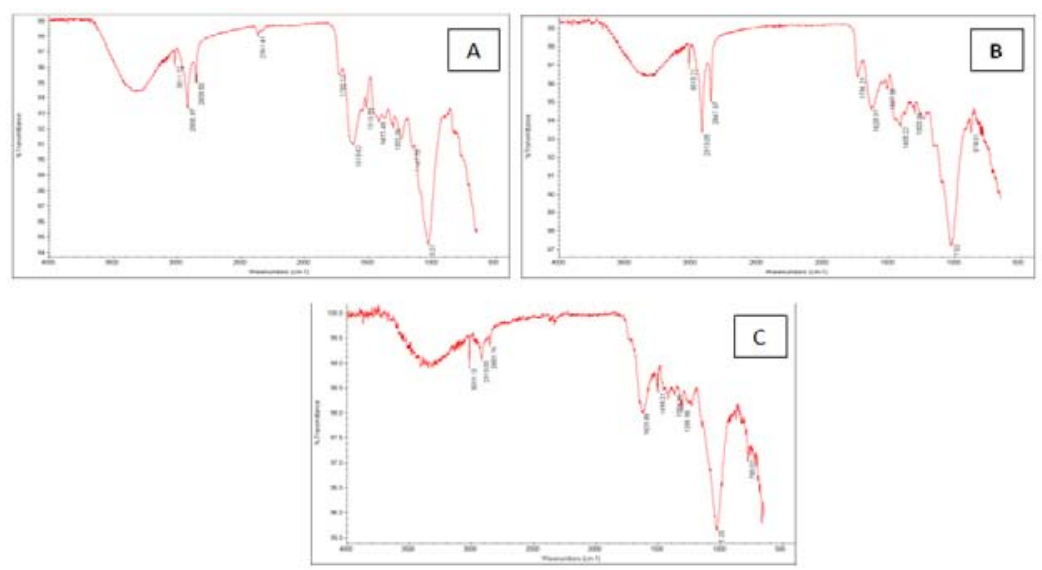

Fig. 6: FT-IR spectrum of A, B and C parts of D. sisso Roxb 
Table 7: FT-IR spectroscopic analysis if A, B and C of D. sisso Roxb

\begin{tabular}{|c|c|c|c|c|c|c|}
\hline Frequency $\left(\mathrm{cm}^{-1}\right)$ & Bonding & Absorption & Interference & $\mathbf{A}$ & B & $\mathbf{C}$ \\
\hline 3011.12 & $\mathrm{C}-\mathrm{H}$ & $\mathrm{s}$ & Aromatic & + & - & + \\
\hline 3015.21 & & & & - & + & - \\
\hline 2908.99 & $\mathrm{C}-\mathrm{H}$ & $w-m$ & Alkane & + & - & - \\
\hline 2913.05 & & & & - & + & + \\
\hline 2839.50 & $\mathrm{C}-\mathrm{H}$ & $\mathrm{w}$ & Aldehyde & + & - & - \\
\hline 2847.67 & & & & - & + & - \\
\hline 2851.76 & & & & - & - & + \\
\hline 1732.12 & $\mathrm{C}=\mathrm{O}$ & s & Aldehyde & + & - & - \\
\hline 1736. 21 & & & & - & + & - \\
\hline 1613.62 & $\mathrm{C}=\mathrm{C}$ & $\mathrm{w}-\mathrm{m}$ & Alkene & + & - & - \\
\hline 1625.88 & & & & - & - & + \\
\hline 1629.97 & & & & - & + & - \\
\hline 1515.55 & $\mathrm{C}=\mathrm{C}$ & $w-m$ & Aromatic & + & - & - \\
\hline 1499.21 & $\mathrm{C}=\mathrm{C}$ & $\mathrm{w}-\mathrm{m}$ & Aromatic & - & - & + \\
\hline 1417.48 & $\mathrm{C}-\mathrm{H}$ & $w-m$ & $-\mathrm{CH}_{3}-$ & + & - & - \\
\hline 1147.79 & $\mathrm{C}-\mathrm{O}$ & $\mathrm{s}$ & Alcohol & + & - & - \\
\hline 874.01 & $\mathrm{CH}$ & $\mathrm{s}$ & - & - & + & - \\
\hline 780.02 & & & & - & - & + \\
\hline
\end{tabular}

\section{DISCUSSION}

Plants are the significant portion of the world to ensure reproducible quality and enhance the consumer confidence for the utilization of herbs as pharmaceutical and commercial industries for raw materials and as well as an active principal [14]. Use of herbal remedies is growing tremendously throughout the world, and this trend is also obvious in Pakistan. Standardization is the key for safety and efficacy of herbal preparations, and this can be achieved only by pharmacognostic studies. On the basis of these studies identification and authentication of herbal drugs has become more appropriate which is also helpful for making monograph of plants. Phytochemical analysis (table 1) revealed that plant parts contain the different types of compounds which authenticated the use of this plant in various ailments and that can be of the valuable therapeutic index and these phytochemicals have been attributed the protective effect of herbal plants [15]. The Moisture content of sample A, B and C of D. sisso were high $99.93 \%, 99.86 \%$ and $99.87 \%$ respectively, hence there is more chance of degradation during the storage, in addition, highest moisture content also worked as moisture aid in stabilizing the plant by maintaining the protoplasmic content of the cells and make it perishable [16]. Total ash value in A and B are $16.15 \%$ and $16.69 \%$ respectively indicating the presence of normal complexes of organic and inorganic components, as maximum accepted limit is $22 \%$, whereas bark showed $22.87 \%$ pointing towards abnormal complexes, higher mineral, metallic salts and silicates, etc. [17]

All three parts of the drug i. e leaves (A) pods (B) and bark (C) exhibit distinguished prominent differentiating organoleptic and histological characters including fibers, calcium oxalate crystals, lignified cells, ground tissues and vessels. All these major macroscopic, microscopic and histological features may be a useful tool for the establishment of standards regarding the apparent morphology, cell shapes, size and arrangement of the cellular structure of the plant. It is one of the economical procedures and necessary for the quantitative evaluation of closely allied herbal raw materials [18]. Fluorescence analysis under the UV at a wavelength of 254-365 nm showing the presence of different primary and secondary metabolites and their UV activations. The different colors of the fluorescence rings are due to different atoms present in the compound having different wavelengths. UV spectrophotometric techniques is one of the most preferred methods for routine analytical work of herbal drugs because of its simplicity and reasonable sensitivity [19]. Functional groups were determined by the use of infrared spectroscopy and reported the different aldehyde alkenes and alcohol etc. these findings are important for the determination of reactivity of samples, which plays an important role in the standardization of the drug. FT-IR spectrum is the scenery of chemical constituents with their functional groups in a complex system and is the most credible method to validate and recognize the material in traditional medicine or herbal medicine [20].

\section{CONCLUSION}

In conclusion, this standardization can serve as a basis for proper identification, collection and investigation of the D. sisso Roxb plant and their utilization as a therapeutic agent. Plant $D$. sisso and its parts $\mathrm{A}, \mathrm{B}$ and $\mathrm{C}$ is first time developed as a standard drug and in addition side to side have important economic advantages that can be utilized as a raw material for the commercial intention, pharmaceutical aid and also in the different formulation for various diseases.

\section{CONFLICTS OF INTERESTS}

Declared none

\section{REFERENCES}

1. A wealth of India Raw material Publication and information directorate CSIR New Delhi; 1972;2:221-30.

2. Chopra RN, Nyer SL, Chopra IC. Supplement to the glossary of Indians Medical plants CSIR New Delhi; 1980. p. 90.

3. Kasa JK, Singh TU, Parida S, Addison MP, Darzi SA, Choudhury $\mathrm{S}$, et al. Assessment of Indian rosewood (Dalbergia sissoo) standardized leaf extract on isoproterenol-induced myocardial injury in rats. Cardiovasc Toxicol 2015;15:250-60.

4. Dixit P, Chillara R, Khedgikar V, Gautam J, Kushwaha P, Kumar A, et al. Constituents of Dalbergia sisso Roxb. leaves with osteogenic activity. Bio Org Med Chem Lett 2012;22:890-7.

5. Kiran VP, Neeraj SV, Rajendra TG, Vilas Murkute. Antidiabetic evaluation of Dalbergia sisso Roxb against alloxan-induced diabetes mellitus in wistar albino rats. J Nat Prod Plant Resour 2012;2:81-8.

6. Nayan R, Rajibul AL, Ismail Sk, Deepa K, Tirthankar G, Naznin AB. A detailed study on the antioxidant activity of the stem bark of Dalbergia sissoo Roxb. an Indian medicinal plant. Food Chem 2011;126:1115-21.

7. Lal HS, Singh S. Ethnomedicinal uses of Dalbergia sissoo Roxb in Jharkhand. Int J Ayurvedic Herbal Med 2012;2:198-201.

8. Harborne JB. Methods of extractions and isolation. In: Phytochemical methods. 3rd ed. Chapman and Hall, London; 1998. p. 60-6.

9. Khursheed R, Rizwani GH, Sharif $H$, Ahmad M Pharmacognostical standardization of leaves of Ricinus Communis L. Int J Pharm Photon 2013;104:321-6.

10. Kokate CK. Practical pharmacognosy. $1^{\text {st }}$ ed. Vallabh Prakashan, New Delhi I; 1986. p. 15-30.

11. Ahmed M, Rizwani GH, Khursheed R, Ishaque S, Huma A, Mahmud S, et al. Comprehensive standardization of stem bark of Pakistani medicinal plant Holoptelea integrifolia (Roxb). Planch according to WHO guidelines. J Ethnobiol Traditional Med Photon 2013;120:602-7. 
12. Peter JH. Establishing identification criteria for botanicals. Drug Inf J 1998;32:461-9.

13. Chase CR, Pratt RS. Fluorescence of powdered vegetable drugs with particular reference to the development of a system of identification. J Am Pharmacol Assoc 1949;38:32.

14. Kokoshi CJ, Kokoshi RJ, Sharma FT. Fluorescence analysis of powdered vegetable drugs under ultraviolet radiation. J Pharm 1958;47:715-7.

15. Shachi S. Phytochemical analysis of different parts of Prosopis juliflora. Int J Curr Pharm Res 2012;4:59-61.

16. Nurul NMN, Norazlanshah H, Muhammad I, Mashita M, Mohd KA. Short Communication preliminary studies on Acalypha indica: proximate analysis and phytochemical screening. Int J Pharm Pharm Sci 2016;8:406-8.

17. Anita S, Sharma RK, Agrawal M, Marshall M. Risk assessment of heavy metal toxicity through contaminated vegetables from wastewater irrigated area of Varanasi, India. Int Soc Trop Ecol 2010;51:375-87.

18. Mukherjee PK. Quality control of herbal drugs. $1^{\text {st }}$ ed. Business horizon publications; 2002. p. 186.

19. Akram MEl-didamony, Sameh $\mathrm{MH}$, Ahmed AS. Extractionspectrophotometric determination of some antihypertensive drugs in pharmaceutical and biological fluids using two sulphonphthalein dyes. Int J Appl Pharm 2015;7:10-7.

20. Undaram S, Palanisamy CP, Velliyur KG. Chromatographic and spectrophotometric analysis of bioactive compounds from Cayratia trifolia L. stem. Int J Pharm Pharm Sci 2016;8:56-4.

\section{How to cite this article}

- Ijaz Ali, Ghazala H Rizwani, Huma Shareef, Sohail Khan Pharmacognostic studies of dalbergia sisso roxb. Int J Pharm Pharm Sci 2016;8(12):48-53. 